\title{
Okul Öncesi Çocuklar İçin Sosyal Duygusal İyi Oluş ve Psikolojik Sağlamlık Ölçeğinin (PERIKK) Geçerlik Güvenirlik Çalışması
}

\author{
DOI: $10.26466 /$ opus.518062 \\ * \\ Saide Özbey*
}

*Doç. Dr. Gazi Üniversitesi Eğitim Fakültesi Temel Eğitim Bölümü Okul Öncesi Eğitimi Anabilim Dalı, Ankara/Türkiye E-Posta: saideozbey@gmail.com ORCID: 0000-0001-8487-7579

Öz

Araştırma "Okul Öncesi Çocuklar İçin Sosyal Duygusal İyi Oluş ve Psikolojik Sağlamlık Ölçeğinin (PERIK)" geçerlik güvenirlik çalışmasını yapmak amacıyla planlanmıştır. Araştırmanın örneklemini Ankara ili Yenimahalle ve Altındă̆ ilçelerinde resmi ve özel okul öncesi eğitim kurumlarına devam eden 36-72 aylık 342 çocuk oluşturmaktadır. Ölçeğin dil geçerliliği altı dil uzmanı tarafindan yapılmıştır. Ölçek maddeleri daha sonra okul öncesi eğitimi alanına ve her iki dile de hâkim üç uzman tarafindan tekrar gözden geçirilerek hem anlaşılırlık açısından hem de orijinalindeki ifadeleri karşılayıp karşılamadiğg test edilmiştir. Son şekli verilen maddeler beş okul öncesi öğretmeni tarafından doldurularak öğretmenler tarafindan anlaşılırlı̆̆ı test edilmiştir. Ölçek faktörleri için Doğrulayıcı Faktör Analizi yapılmış ve ölçeğin orijinalindeki 6 faktörlü yapısı doğrulanmıştır. Ölçeğin uyum indeksleri incelendiğinde ölçeğin iyi ve mükemmel uyum gösterdiği saptanmıştır. Ölçeğin faktörleri arasındaki korelasyon için Pearson Korelasyon Testi yapılmış ve ölçeğin faktörleri arasında orta ve yüksek düzeyde ve anlaml ilişki olduğu belirlenmiştir. Ölçeğin Alpha güvenirlik katsayıları 86 ile 95 arasında değişmektedir. Araştırma sonucunda ölçeğin Türk çocukları için geçerli ve güvenilir bir ölçme aracı olduğu saptanmıştır.

Anahtar Kelimeler: Okul öncesi, çocuk, psikolojik sağlamlık, sosyal duygusal iyi oluş.

OPUS (c) Uluslararası Toplum Araştırmaları Dergisi-International Journal of Society Researches ISSN:2528-9527 E-ISSN : 2528-9535

http://opusjournal.net 


\title{
Validity and Reliability Study of Social Emotional Well-Being and Psychological Resilience Scale for Preschool Children (PERIK)
}

\begin{abstract}
The research was designed to conduct the validity and reliability study of the "Social Emotional Wellbeing and Psychological Resilience Scale for Preschool Children (PERIK)" developed by Mayr and Ulich (2009). The sample of the study consists of 342 children in the ages of 36-72 months attending to the public and private preschools in the districts of Yenimahalle and Altındağ in Ankara. The language validity of the scale was conducted by six language specialists. The items of the scale were reviewed subsequently by three specialists who have good command of the field of preschool education and of both languages. They tested the scale for comprehensibility and checked whether the items correspond to the original statements. The finalized items were filled in by five preschool teachers and it comprehensibility of the items was tested. Confirmatory Factor Analysis was conducted for the factors of the scale and the 6-factor structure in the original scale was confirmed. The fit indices of the scale were examined and the scale was found to have a good and perfect fit. Pearson Correlation test was conducted for the correlation between the factors of the scale and it was determined that there was a medium and high significant relation between the factors of the scale. The Alpha reliability coefficients of the scale vary between .86 and .95 . As a result of the study, it was found that the scale is a valid and reliable measurement instrument for the Turkish children.
\end{abstract}

Keywords: Preschool, child, psychological resilience, social emotional well-being

OPUS (c) Uluslararası Toplum Araştırmaları Dergisi-International Journal of Society Researches ISSN:2528-9527 E-ISSN : 2528-9535

http://opusjournal.net 


\section{Giriş}

Sosyal ve duygusal iyi oluş sosyal ve duygusal gelişim kapsamında duyguları, davranışları, ilişkileri, hedefleri ve kişisel güçleri içeren geniş bir terimdir. Sosyal ve duygusal gelişim, çocukların okulda ve genel olarak hayatta başarılı olmak için geliştirmeleri gereken bazı becerileri kapsar. Bunlar kişinin, duyguları tanımlama ve anlama, başkalarının duygusal durumlarını doğru okuma ve anlama, güçlü duyguları yönetme, davranışlarını düzenleme, empati kurma ve kişilerarası ilişkileri başlatma ve sürdürme becerileridir. Sosyal ve duygusal gelişim "ruh sağlığı" "psikososyal yeterlilik" gibi karşılaşılan zorluklarla başa çıkmak için gerekli güç ve kapasiteyi içinde barındıran, üretken bir yaşam sürmeye ve hem kendine hem de bulunduğu topluma katkı sağlamaya fırsat veren psikolojik sağlamlıkla (resilience) ilgilidir (Hamilton ve Redmond, 2010; Graham, 2011).

Psikolojik sağlamlık (resilience) yaşam boyunca ortaya çıkmakta yaşa, cinsiyete ve kültürlere göre farklılık göstermektedir. Araştırmacılar 1950 ve 1960'lı yıllarda bazı çocukların oldukça ağır ve dezavantajlı durumlardan olağanüstü bir şekilde nispeten zarar görmemiş olarak çıkabilme nedenlerini merak ederek araştırmaya başlamışlardır. Esneklik (resilience) olarak da ifade edilen psikolojik sağlamlığı araştıran ilk çalışmalar yetişkin travmasına ve gelişim psikolojisine yönelerek travmatik stresten kaçınmak için bireylere neyin öncülük ettiğini belirlemeye odaklanmıştır. Gelişim psikolojisi psikolojik sağlamlığa etki eden kişisel nitelikleri inceleyerek gelişim sürecindeki benlik saygısı, sosyal ve ekonomik dezavantajlar, ihmal ve istismar ya da yaşamdaki felaket durumlarının nispeten kötü sonuçlarını irdelemişdir. Werner ve Smith (1982) psikolojik sağlamlık çalışmalarında değerlilik duygusu, aile desteği ve başa çıkma becerilerinin psikolojik sağlamlığa önemli etken olduğu sonucuna ulaşmışlardır. Psikolojik sağlamlık kavramı çocukların sıkıntıya tepkisine odaklanan gelişimsel psikapataloji, insan gelişiminde olumlu duygu ve ilişkilere odaklanan pozitif psikoloji, insanı anlama ve kazanmaya odaklanan hümanistik psikoloji ve giderek sağlık psikolojisi, nörobiyolojik psikoloji gibi birçok disiplin tarafından ele alınarak çalışılmaktadır (Graber, Pichon ve Carabine, 2015). 
Erken dönemdeki klinik vaka çalışmalarında bazı çocukların zorluklarla başa çıkabilir iken bazılarının zorluklara yenik düşmesi dikkati çekmiştir. Örneğin Bleuler (1984) (Akt: Anthony,1987:147-184) tarafından tanımlanan annesi akıl hastanesine yatırılan 14 yaşındaki İsviçreli bir kız çocuğunun annesinin yokluğunda kardeşlerine bakıp büyütmesi, alkolik bir babaya bakması ve sonrasında mutlu bir evliliğe ve hayata sahip olması ve Werner'in Hawai'deki yüksek risk ortamında doğan bebeklerle yaptığı ve 14 yıl süren çalışması bu günkü psikolojik sağlamlıkla ilgili bilgilerin temelini oluşturmaktadır (Akt: Alvord ve Grados, 2005). Werner'in Hawaii'deki çocuklara dair çı̆̆ır açan çalışmalarının ardından (Werner, Bierman ve French, 1971; Werner ve Smith,1977), psikolojik sağlamlık üzerine yapılan araştırmalar, sosyoekonomik dezavantaj, kronik yoksulluk, ebeveyn ruh hastalıkları, toplumsal şiddet, kentsel yoksulluk ve ilgili riskler gibi birçok olumsuz durumu kapsayacak şekilde genişlemiştir. İlk yapılan çalışmalar psikolojik açıdan sağlam olan çocukların öncelikle özerklik veya yüksek benlik saygısı gibi kişisel özelliklerine odaklanmıştır. Bununla birlikte, alandaki çalışmalar geliştirildikçe araştırmacılar, psikolojik sağlamlığın sıklıkla çocuğun dışındaki faktörlerden kaynaklanabileceğini kabul etmiştir. Daha sonraki araştırmalar, psikolojik sağlamlığın gelişiminde rol oynayan üç faktör grubunun tanımlanmasına yol açmıştır: (1) çocukların kendileri, (2) ailelerinin özellikleri ve (3) daha geniş sosyal ortamlarının özellikleri (Masten ve Garmezy, 1985; Werner ve Smith, 1982, 1992'den akt: Luthar, Cicchetti ve Becker, 2000).

Psikolojik sağlamlık bireysel bir özellik olmaktan çok öğrenilebilen ve geliştirilebilen bir davranış biçimi olarak ele alındığı için kalıcı bir özellik olarak görülmemektedir. Psikolojik açıdan sağlam olarak değerlendirilen bireyler belirli bir süre sonra psikolojik açıdan sağlamlıklarını yitirebilirler. Psikolojik sağlamlık gösteren bireyler olağanüstü kişiler olmayıp; güç koşullarda normal gelişim gösteren bireylerdir (Bektaş ve Özben, 2017). Psikolojik olarak sağlam bireyler, strese karşı en dirençli olup ağır stres meydana getiren olaylar karşısında fiziksel ya da duygusal bozukluğa uğramayan kişilerdir (Atkinson, Atkinson, Smith, Bem ve Nolen-Hoeksema,1999'den akt: Sipahioğlu, 2008).

Yapılan çalışmalarda psikolojik sağlamlık birçok şekilde tanımlanmıştır. Garmezy'nin (1990) “zorlu veya tehdit edici koşullara 
rağmen başarılı adaptasyon süreci, kapasitesi, ya da sonucu olarak" yaptığı tanım alandaki daha aşina olunan ve geniş çapta kabul edilen tanımlardan birisidir (Masten, Best ve Garmezy,1990). Murphy'e (1987) göre psikolojik sağlamlık, "bir çocuğun stresle nasıl baş ettiği ve travmadan nasıl kurtulduğu/iyileştiği ile ilgilenen genel bir kavramdır. Psikolojik sağlamlık, olumlu baş etmenin sonuçları olan uyum (adaptation) ve yeterlik (competence) gibi olumlu gelişme, geleceğe yönelme ve umut ile ilgilidir" (Akt: Gizir, 2016). Psikolojik sağlamlık "ağır stres oluşturan durumlarda olumlu adaptasyonu içeren dinamik bir süreçtir" (Luthar, Cicchetti ve Becker, 2000). Fraser, Richman ve Galinsky (1999)'ye göre psikolojik sağlamlık "bireyin belli kişisel özellikleri ve çevresindeki faktörler arasındaki etkileşim" olarak tanımlanmaktadır (Akt: Karairmak, 2006). Fraser, Richman ve Galinsky (1999) psikolojik sağlamlığı "olağanüstü/sıradışı koşullara uyum sağlama becerisi ve zor koşullar altında olumlu ve beklenmedik başarılar kazanma" olarak tanımlamaktadırlar. Karaırmak (2006) 'a göre psikolojik sağlamlık, "bireyin olumsuz bir durum ile karşı karşıya geldiğinde, risk faktörleri ve koruyucu faktörlerin etkileşimi sonucunda hayatındaki değişikliğe uyum göstermesi" dir. Earvolino-Ramirez (2007) ise psikolojik sağlamlığ1 "hastalık, depresyon veya bir başka kötü durumdan çabucak iyileşme, toparlanma ve eski haline kolayca dönebilme yeteneği" olarak tanımlamışlardır (Akt: Ağırkan ve Kağan, 2017).

Psikolojik sağlamlık kavramı Latincede "resiliens", İngilizcede "resilience" kelimesine karşılık gelmekte olup, "bir maddenin elastik yapısıyla kolayca aslına dönebilmesi" olarak tanımlanmaktadır (Greene, 2002). Bükülen, gerilen, preslenen bir maddenin ya da nesnenin esneyerek tekrar orijinal şekline geri dönmesidir (Macmillandictionary,2018). Kavramın dilimizdeki karşılı̆̆ında ise çeşitlilik bulunmakla beraber, "sağlamlık", "dayanıklılık", "yılmazlık", "güçlülük", “toparlanma", "psikolojik dayanıklılık" ve "psikolojik sağlamlık" gibi tanımlamalar yapılmıştır (Bektaş ve Özben,2017).

Jeanne ve Jack Block (1980) tarafından geliştirilen ve psikolojik sağlamlık (resiliency) ile karıştırılan ego sağlamlığı bireylerin kişisel özelliklerine değinen bir yapıdan türetilmiştir. Ego sağlamlığı, karakterin genel becerikliliğini ve sağlamlığını yansıtan bir dizi özelliği ve değişen çevresel koşullarına yanıt olarak süreç içerisindeki esnekliği kapsar. Blok 
(1969) ego-sağlamlığını "dünyayla bağlantılı ama ona bağlı olmayan" ve "stres altında entegre performans" olarak ifade etmektedir. Sağlamlık terimi ego-sağlamlık terimiyle birbirinin yerine kullanılıyor gibi görünse de gerçekte bu iki terimin farklılıklarının dikkate alınması gerekmektedir. Herhangi bir olumsuz durum ego sağlamlığı güçlü bir çocuk tarafından deneyimlendiğinde bu durumun psikolojik sağlamlık (resiliency) olarak değerlendirilmesi uygun görülmemektedir. Ego sağlamlığ ve psikolojik sağlamlık iki ana boyutta farklılık göstermektedir. Birincisi ego sağlamlığı bireyin kişilik özelliği iken, psikolojik sağlamlık dinamik bir gelişim sürecidir. İkincisi ise ego-sağlamlığı büyük ölçüde olumsuzluğa maruz kalmayı öngörmez iken psikolojik sağlamlık bu öngörüye sahiptir (Akt: Luthar, 1996). Masten (1994) psikolojik sağlamlık teriminin sadece zorlu yaşam koşulları altında pozitif uyumun sürdürülmesinden bahsederken kullanılmasını önermiştir (Luthar, Cicchetti ve Becker, 2000).

Mayr ve Ulich (2003) boylamsal çalışmalar sonucunda psikolojik açıdan sağlam kişilik özelliklerini, pozitif sosyal ilişkileri olan, empati kurabilen, sosyal becerilere sahip, sebatkar, olumlu benlik algısına sahip, duygularını doğru ifade edebilen, iyimser, canlı ve neşeli, sakin ve rahat olabilen, bağımsız ve özerk davranabilen, problem çözme becerisi gelişmiş, ilgi alanları ve hobileri olan, meraklı ve araştırmacı, yeni deneyimler edinmekten hoşlanan ve zorluklarla karşılaştığında tekrar toparlanabilme becerisine sahip bireyler olarak ifade etmektedirler (Akt: Mayr ve Ulich 2009).

Psikolojik sağlamlık kavramının; "önemli tehdit veya ağır sıkıntıya maruz kalma" ve "gelişimsel sürece yönelik büyük saldırılara rağmen olumlu adaptasyonun sağlanması" olmak üzere iki boyutu bulunmaktadır (Luthar, Cicchetti ve Becker, 2000; Miljević-Riđički, Plantak ve Bouillet,2017). Birçok psikolojik sağlamlık tanımı, tanımlanmış bir risk veya bireyin maruz kaldığı bir zorluğun varlığını gerektirir, bunu takiben belirli bir pozitif sonuç ölçüsü süreci takip eder. Bununla birlikte, psikolojik sağlamlığı neyin oluşturduğuna ve başarılı bir şekilde uyumluluğa nasıl başarılı bir şekilde karşılık verileceğine ilişkin tartışmalar sürmektedir. Bazıları, esnek bir insanın, yaşamının çeşitli dönemlerinde zaman içinde olumlu sonuçlar göstermesi gerektiğini öne sürmüştür. Psikolojik sağlamlık kişilerin sahip olduğu ya da sahip olma- 
dığı tek boyutlu bir özellik değildir. Daha çok bireylerin başa çımasına yardımcı olan, farklı derecelerdeki çoklu becerilere sahip olmayı gerektirir (Cicchetti ve Rogosch, 1997 ve Reivich ve Shatte, 2003'den akt: Alvord, ve Grados, 2005). Boşanma, terör, doğal afetler, savaşlar, yoksulluk, aile içi düzensizlikler, ağır hastalıklar vb. olumsuz durumlarla karşılaşıldığında koruyucu faktörler ile risk faktörlerinin etkileşimiyle ortaya çıkan süreç içerisinde bireyin hayatındaki bu değişikliklere uyum sağlayabilme becerisini göstermektedir. Çocukların olumsuz koşullar ve stres altında sergiledikleri psikolojik sağlamlık, kişilik özellikleri ve çevresel faktörlerin etkisine bağlı olarak farklılık gösterebilmektedir (Wang, 1995; Karairmak, 2006; Bektaş ve Özben, 2017). Psikolojik sağlamlık stresin olumsuz etkilerini azaltan ve uyumu destekleyen kişilik özelliği olarak gören bazı araştırmacılar bireylerin genetik özelliklerine odaklanmış ve psikolojik sağlamlığın doğuştan getirilmiş bir kişilik özelliği olduğunu öne sürmüşlerdir. Ancak yapılan çalışmalar psikolojik sağlamlığın öğrenilen ve gelişimsel süreç içerisinde gelişen desteklenen bir kişisel özellik olduğunu ortaya çıkarmıştır (Basım ve Çetin, 2010).

Luthar, Cicchetti ve Becker (2000) ve Green (2002), psikolojik sağlamlığ1 birey, aile ve çevresel faktörlerin etkileşimiyle gerçekleştiği için ekolojik bağlamda ele alınması gerektiğini belirtmektedirler. Ungar (2011) da psikolojik sağlamlığın bireyin kişisel özelliklerine ve onun sosyal ve fiziksel bağlamına daha az bağlı olduğunu vurgulamakta ve olumsuzluk altında pozitif büyümeye yardımcı olabilecek ekolojik koşullara daha fazla odaklanılması gerektiğini öne sürmektedir. Ferić, Maurović ve Žižak (2016) ise psikolojik sağlamlığın bireye odaklanmasından daha geniş bir çevreye odaklanmak için geliştirilmiş bir kavram olduğunu vurgulamaktadır. Masten (1997) bir felaketin neden olduğu stres faktörlerinin çocuğun düşünme ve problem çözme becerileri üzerinde olumsuz etki bıraktığını ancak ebeveyn ve diğer sosyal ilişkilerinin ve bilişsel becerilerinin güçlü olduğu durumlarda en sıkıntılı durumlarda bile çocuğun psikolojik olarak sağlam bir duruş gösterilebileceğini ifade etmektedir.

Bronfenbrenner (1979) mikro, makro, mezo ve ekosistem olmak üzere birbirine geçmiş dört sistemin olduğunu, bu sistemlerin birbiriyle etkileşim içinde bulunduğunu bu etkileşimin ise bireyin davranışları 
üzerinde şekillendirici olduğunu belirtmektedir. Mikro sistem içerisinde aile, akrabalar, iş yaşamı ve komşular gibi yakın sosyal çevre bulunmaktadır. Bireyin yaşadığı mikro sistem bireyin eylemlerine etki etmektedir. Psikolojik sağlamlığın çok boyutlu yapısını açıklamada "Ekolojik Kuram" kişilerarası değişkenlerin etkileşimine dikkat çekerek kavramın anlaşılmasını kolaylaştırmaktadır.

Çocuklar psikoloji sağlamlık açısından bir kapasiteye sahip olarak dünyaya gelmektedirler. Psikolojik sağlamlık yaşam boyunca üzerinde çalışılan bir durumdur. Bu nedenle erken dönemlerde psikolojik sağlamlığ güçlendirmeye çalışmak önem taşımaktadır. Erken çocukluk döneminde çocuklar ebeveynleri izleyerek günlük stres yaratan olaylarla nasıl başa çıktıklarını gözlemleyerek öğrenmektedirler. Çocuklar büyüdükçe hem aile hem de okul yaşamlarında yeni bilişsel, sosyal ve davranışsal beklentiler giderek artmaya başlamaktadır. Okul öncesi dönemde erken gelişimsel görevleri üstlenemedikleri takdirde yeni gelişimsel görevleri ve okul yaşamıyla birlikte akademik talepleri karşılamak gittikçe zorlaşabilmektedir. $\mathrm{Bu}$ nedenle psikolojik sağlamlığın (resilience) nasıl geliştirileceğinin anlaşılması ve çocuğun bu noktada desteklenmesi önem taşımaktadır. Psikolojik sağlamlığın en tutarlı belirleyicilerinden birisi ebeveyn desteğidir. Destekleyici ve duyarlı bakım verme, duygu düzenleme becerileri, sosyal beceriler ve akademik yetkinliğin desteklenmesi sıkıntıya maruz kalan çocuklarda daha az saldırgan davranışların gelişmesine destek olacaktır. Çocukların okul öncesi dönemde üstlenmeleri gereken gelişimsel görevler arasında duygu düzenleme, sağlıklı akran ilişkileri geliştirme, okula hazır bulunuşluk vb. görevler bulunmaktadır. $\mathrm{Bu}$ gelişimsel görevleri başarılı bir şekilde gerçekleştiremeyen çocuklar, okulda ve okul öncesi ve sonrasında sağlıklı ilişkilerin geliştirilmesinde daha fazla zorluk yaşama eğilimindedirler. Çocukların duygusal düzenleme becerileri olumlu ve olumsuz duygularını yönetebilme, istenmeyen dürtü ve davranışlarını engelleyebilme, duygusal problemlerden kurtulma ve yeteneklerinin farkına varabilme becerileri desteklenerek geliştirilmektedir. Duygusal zorluklardan kurtulma becerisi, stres ve olumsuz deneyimlerle ilgili daha etkili başa çıkma becerilerini de destekler. Ayrıca, duygu düzenlemesinin çocukların sosyal, akademik ve kişisel işlevleriyle ilişkili olduğu saptanmıştır. Duygu düzenlemesi sık strese maruz kalmanın 
olumsuz etkilerini yaşan çocuklar için özellikle önemlidir (Yule, 2017). Howell, Graham-Bermann, Czyz ve Lilly (2010) psikolojik sağlamlığ okul öncesi çocukların gelişiminde hayati öneme sahip iki alan olan duygu düzenleme ve olumlu sosyal becerilerde güçlülük olarak kavramsallaştırmışlardır. Davranışlarını ve duygularını etkileşimde ve yönetmede daha yetkin hale gelmek, çocukların sosyal becerilerini geliştirerek başkalarıyla daha fazla etkileşimde bulunmalarını sağlar. Akranlarıyla olumlu ilişkilerin kurulması ise okul öncesi ve ilkokul yıllarında ruh sağlığı açısından önemli görülmektedir. Okul öncesi dönemde duygu düzenlemesi, sosyal beceriler, okula hazır bulunuşluk ve problemli davranışlar psikolojik sağlamlığın geliştirilmesinde ele alınması gereken temel konular olarak görülmektedir (Denham, 2006; Yule, 2017).

Küçük çocuklarda sağlıklı gelişmeyi destekleyen şeylerin çoğu aynı zamanda psikolojik sağlamlıklarını geliştirmeye yardımcı olur. Okul öncesi dönemde bilişsel açıdan desteklenen çocuklar sosyal ve duygusal açıdan daha iyi durumda olabileceklerdir (Hall, Sylva, Melhuish, Sammons, Siraj-Blatchford ve Taggar, 2009). Bununla birlikte sağlıklı gelişimin desteklenmesi, bakım veren bir yetişkinle güvenli bir bağ, olumlu rol modelleri ile ilişkiler, becerilerini öğrenme fırsatları, anlamlı etkinliklere katılma fırsatları şeklinde açıklanabilir. Aile ve aile dışındaki arkadaş oyun vb. gruplar, sosyal ortamlar, okul çocukların psikolojik sağlamlıklarının desteklenmesinde rol oynayan dışsal kaynaklardır. Bununla birlikte, özgüven, öz denetim, olumlu düşünme becerileri çocuğun kendine ait içsel kaynaklar olarak değerlendirilmektedir (Best Start Resource Centre, 2018).

Çocukların psikolojik sağlamlıklarının desteklenmesi için yetişkinlerin gelişim sevgi ve sayıya dayalı sıcak ilişkiler kurmaları, çocuğa güvende olduğunu hissettirmeleri, çocuklarla birlikte hem fiziksel hem de hayal güçlerini geliştirecek oyun ortamları oluşturmaları, sosyal becerilerini destekleyecek ortamlar sunmaları önem taşımaktadır. Bununla birlikte çocuklar korktuğunda ya da üzüldügünde onları rahatlatmaları çocukların kendilerini yalnız hissetmemelerine fırsat verecektir. Çocukların duygu ve düşüncelerini dinlemek kendilerini değerli hissetmelerine yardımcı olacaktır. Çocukların yaşadıkları olaylar karşısında hissettiklerini anlayabilmek için empatik yaklaşımların sergilenmesi 
çocuklara da empatik bakış açısı kazandıracaktır. Televizyon izleme vakitlerinin azaltılması ve çocuklarla birlikte kitap okuma, parka gitme, ev işlerini yapma vb. aktivitelerin planlanması çocuklarda psikolojik sağlamlığın desteklemede ayrı bir yere sahiptir (Best Start Resource Centre,2018). Howell, Graham-Bermann, Czyz ve Lilly (2010) ve Howell, (2011) çalışmalarında psikolojik sağlamlık kavramını duygu düzenleme ve sosyal beceriler olarak ele alarak ebeveynlik becerileri, ebeveynin ruh ve beden sağlığı ile çocukların psikolojik sağlamlıkları arasında pozitif ilişki bulunduğunu saptamışlardır. Araştırmada ayrıca çocukların şiddete maruz kalma durumlarıla psikolojik sağlamlıkları arasında negatif yönde ilişki bulunduğu saptanmıştır. Başka bir ifadeyle etkili ebeveyn ilişkilerine sahip beden ve ruh sağlığ yerinde olan ve şiddete maruz kalmayan çocukların psikolojik sağlamlıklarının daha iyi düzeyde olduğu belirlenmiştir (Howell, Graham-Bermann, Czyz ve Lilly 2010; Howell, 2011).

Psikolojik sağlamlığı desteklenen çocukların yetişkinlik dönemlerinde zorluklar karşısında daha dayanıklı oldukları, daha sağlıklı ve uzun yaşadıkları, ilişkilerinde daha mutlu, okulda ve işlerinde daha başarılı, depresyona girme olasılı̆̆ı daha düşük olduğu belirtilmektedir (Best Start Resource Centre,2018). Bu nedenle okul öncesi dönemin yetişkinlik dönemine kaynaklık edecek gelişimsel alt yapı oluşturduğu dikkate alınacak olunursa, psikolojik sağlamlığın okul öncesi dönemden itibaren desteklenmesi gerektiği düşüncesi tartışılamaz bir gerçektir. Yapılan literatür taramasında psikolojik sağlamlıkla ilgili çalışmaların okul öncesi dönemde oldukça sınırlı olduğu daha çok yetişkinlere yönelik yapılan çalışmaların bulunduğu görülmüştür (Sipahioğlu,2008). Her ne kadar okul öncesi dönemde psikolojik sağlamlığa kaynaklık eden sosyal beceriler, duygu düzenleme, kaygı, duygusal zekâ, öz düzenleme, özgüven ile ilgili yapılmış çalışmalar bulunsa da psikolojik sağlamlığı bir bütün olarak ele alan çalışmalar ve psikolojik sağlamlığı okul öncesinde ölçebilecek ölçme araçları da oldukça sınırlıdır. Önder ve Gülay Ogelman (2011) Okul Öncesi Çocuklar İçin Ego Sağlamlık Ölçeğinin geçerlik ve güvenirlik çalışmasını yapmışlardır. Ünsal ve Uyanık Balat (2016) ise Psikolojik Dayanıklılık Programının çocukların sosyal becerilerine etkisini ortaya koyan bir çalışma gerçekleştirmişlerdir. Erdem (2017) çalışmasında okul öncesinde çocukların yılmazlık özellikleri ve 
yılmazlığ 1 destekleyici faktörleri incelemiş ve çalışmasında risk altındaki çocukları örneklem grubuna alarak söz konusu grupta yılmazlık özellikleri taşıyan çocukları belirlemiş ve yılmaz çocuk özelliklerini saptamıştır. Şahan Aktan ve Önder (2018) çalışmalarında psikolojik dayanıklılığın kuramsal temellerini irdeleyerek okul öncesi çocuklar için psikolojik sağlamlık kavramını açıklamaya çalışmış ve psikolojik sağlamlığ geliştirme konusunda önerilerde bulunmuşlardır. Balaban Dagal ve Bayındır (2018) Önder ve Gülay Ogelman (2011) tarafından geçerlik güvenirliği yapılan Ego Sağlamlık Ölçeğini kullanmışlar ve okul öncesi çocukların ego sağlamlık düzeylerini bazı değişkenlere göre incelemişlerdir. Çalışmada kız çocuklarının ego sağlamlık düzeylerini erkek çocuklarına göre daha yüksek düzeyde olduğunu saptanmıştır.

Yapılan çalışmalar incelendiğinde psikolojik sağlamlık kavramının okul öncesi dönemdeki çocuklarda çalışılmaya başlandığ 1 ancak hem yapılan çalışmaların hem de psikolojik sağlamlığı ölçebilecek ölçme araçlarının yeterli olmadığı görülmektedir. Okul öncesi dönemde psikolojik sağlamlığı ölçebilecek farklı ölçme araçlarının geliştirilmesi ve alan yazına kazandırılması önem taşımaktadır.

Bu nedenle bu araştırma Mayr ve Ulich (2006), Mayr ve Ulich (2009) tarafından geliştirilen “Okul Öncesi Çocuklar İçin Sosyal Duygusal İyi Oluş ve Psikolojik Sağlamlık Ölçeğinin" geçerlik ve güvenirliğini yapmak amacıyla planlanmıştır. Ölçeğin hem sosyal duygusal iyilik halini hem de psikolojik sağlamlığı ölçmesi ölçeği diğer ölçme araçlarından ayıran en önemli özelliğidir. Araştırmada "Okul Öncesi Çocuklar İçin Sosyal Duygusal İyi Oluş ve Psikolojik Sağlamlık Ölçeği (PERIK)"36-72 aylık çocuklar için geçerli ve güvenilir bir ölçme aracı mıdır? Sorusuna cevap aranmıştır. Araştırmanın okul öncesi dönemde psikolojik sağlamlıkla ilgili yapılacak önleyici ve müdahale çalışmalarına ışık tutacağ1 düşünülmektedir.

\section{Yöntem}

\section{Evren ve Örneklem}

Araştırmanın evrenini Ankara ili Yenimahalle ve Altındağ ilçelerinde resmi ve özel okul öncesi eğitim kurumlarına devam eden 36-72 aylık 
10485 çocuk oluşturmaktadır. Araştırmanın örneklemini evrenden tesadüfi küme örnekleme yoluyla seçilmiş 342 çocuk oluşturmaktadır. Örneklem büyüklüğü Saraçoğlu ve Orhan (2007) tarafından önerilen formül doğrultusunda hesaplanmıştır. Formülde $\mathrm{p}$ anlamlılık değeri 0.05 , tabloda karşılık gelen $\mathrm{t}$ değeri 1.96 ve $\mathrm{PQ}=.25$ 'tir. Buna göre 342 çocuk evreni \%90-\%95 güven aralığında temsil etmektedir (Saraçoğlu ve Orhan, 2007). Tesadüfi küme örnekleme yönteminde evren küme adı verilen gruplara ayrılarak her küme bir örnekleme birimi olarak tanımlanmaktadır. Örneklem tek tek bireylerle değil tesadüfi yolla seçilen grupların bir araya getirilmesiyle oluşturulmaktadır. Tesadüfi seçilen grupların elemanları benzer özelliklere sahiptir. Örneğin tesadüfi yolla çocukları sınıflardan tek tek seçmek yerine örnekleme girecek sinıflar ve bu sınıflardaki tüm bireyler örneklem olarak alınır (Çömlekçi, 2001, s.90; Özen ve Gül, 2007). Örnekleme alınan çocukların \%50.3’ü kız ( $n=172) \% 49.7$ 'si (n=170) erkektir. \%11.4'ü 36-48 aylık; (n=39), \%48.2'si 4960 aylık; \% 40.4'ü (n=138) ise 61-72 aylıktır.

\section{Veri Toplama Aracı}

Araştırmada veri toplama aracı olarak Mayr ve Ulich (2009) tarafından geliştirilen “Okul Öncesi Çocuklar İçin Sosyal Duygusal İyi Oluş ve Psikolojik Sağlamlık Ölçeği" kullanılmıştır.

\section{Okul Öncesi Çocuklar İçin Sosyal Duygusal İyi Oluş ve Psikolojik} Sağlamlık Ölçeği (PERIKK): Ölçeğin geliştirilme sürecinde çocukların sağlıklı sosyal ve duygusal gelişimine odaklanılarak uzun yıllar yapılan deneysel çalışmalar sürecinde çocukların gözlemlenmesiyle ölçeğin teorik alt yapısı güçlendirilmiştir. Mayr ve Ulich (2009) çocukların eğitimiyle ilgilenen tüm öğretmenlerin ve ailelerin çocukların sağlıklı, mutlu öğrenmeye açık olabilmeleri için çocukların sosyal ve duygusal iyi oluş durumlarının olağanüstü önemli olduğunu ve çocukların mutluluğunun eğitim kurumlarının ve uygulanan programların kalitesinin göstergesi olduğunu belirtmektedirler.

Mayr ve Ulich (2009) “iyi oluş (well-being)" ve "pozitif gelişim (positive development)" kavramlarına odaklanarak bu kavramların iyi tanımlanıp ölçmek için de geçerli ve güvenilir ölçme araçlarının olması 
gerektiği düşüncesinden hareketle yola çıkmışlardır. Ölçek "ruh sağlığ1 (mental health)", "psikolojik sağlamlık (resilience)" ve "okula hazırbulunuşluk (school readiness)" kavramları temelinde geliştirilmiştir. Söz konusu kavramların ortaya çıkması uzun yıllar yapılan çalışmalar sonucunda gerçekleşmiştir.

Fiziksel ve zihinsel iyi oluş ve pozitif gelişim üzerine son 30 yıldır yapılan çalışmalar üzerine sistematik olarak yoğunlaşan araştırmalar sonucunda pozitif gelişim kavramı ortaya çıkmıştır. Becker (1986) çalışmasında fiziksel iyi oluş (physical well-being), olumlu ve olumsuz duygular (positive feelings, seldom negative feelings), yüksek düzeyde enerji (high level of energy), yaşam becerileri (life skills), doğallık, atılganlık, kendini gerçekleştirme gibi kavramlara odaklanmıştır. Yaşam becerilerinden kastedilen benlik algısı, stresle başa çıkma becerileri, iletişim ve sosyal yeterlilik, yaratıcı ve bağımsız düşünme ve problem çözme becerileridir. Psikolojik sağlamlık (resilience) kavramı risk altındaki çocukların tüm olumsuz koşullara rağmen ileriki dönemlerinde sağlıklı ve mutlu yaşam biçimine sahip olabilmesi durumuna odaklanmıştır. "Okula hazırbulunuşluk" (school readiness) ise çok farklı karmaşık bir yapıyı içinde barındırmaktadır. Çocukların okula hazır olabilmeleri, dikkat kontrolü, planlama becerileri, bağımsız çalışabilme, sebat gibi bilişsel düzenlemeleri, duygu ve davranış kontrolünü ve kişilerarası iletişim ve etkileşim gibi sosyal yeterlilikleri kapsamaktadır. Erken dönemdeki sosyal yeterlilikler çocuğun sonraki yaşamında daha etkili akran ve öğretmen ilişkilerinin gelişmesine temel oluşturarak öğrenme performansı üzerinde etkiye sahiptir (Akt: Mayr ve Ulich, 2009).

Sosyal duygusal yeterliliklerin pozitif gelişimin temelini oluşturması ölçeğin geliştirilme sürecinde önemli görülmüştür. Mayr ve Ulich (2009), pozitif gelişimin kesin olarak tanımlamak ve pozitif gelişime ulaşmanın yollarını aramak düşüncesiyle deneysel çalışmalarını yaparak ölçek geliştirme sürecini gerçekleştirmişlerdir. Geniş çaplı ve uzunlamasına yapılan deneysel çalışmalar ölçeğin maddelerinin ortaya çıkmasına kaynaklık etmiştir. İlk çalışmalar 78 madde ile başlamıştır.

Ölçeğin geliştirilme sürecinde ilk deneysel çalışmada 171 ikincisinde ise 309 çocukla Mayr ve Ulich $(1999,2003)$ tarafından geçerlik güvenirliği yapılarak 11 alt ölçeğe ulaşılmıştır. Bu ilk çalışmadan sonra ölçek 
kapsamlı bir şekilde gözden geçirilmiştir. Ölçeğin ikinci deneme versiyonu 85 madde olup 30 anaokulunda 351 çocuk gözlemlenerek uygulanmıştır. Ölçekle ilgili çalışmalar sonraki yıllarda da devam etmiştir (Mayr ve Ulich (2006).

Ölçekle ilgili yapılan son çalışmada (Mayr ve Ulich (2006) ölçeğin 6 alt ölçekli ve 36 maddelik son haline ulaşılmıştır. Ölçeğin geçerlik güvenirlik çalışmaları kapsamında faktör yapısı incelenmiş madde toplam korelasyonuna bakılmış ve Alpha güvenirlik katsayıları hesaplanmıştır. Açımlayıcı faktör analizinde ölçeğin İletişim Kurma / Sosyal Performans, Öz-Kontrol/ Düşüncelilik, Atılganlık, Duygusal İstikrar/Stresle Başa Çıkma, Görev Yönelimi, Keşfetmekten Hoşlanma olarak adlandırılmış 6 alt ölçekten oluştuğu saptanmıştır. Ölçek her alt ölçekte 6 madde olmak üzere toplamda 36 maddeden oluşmaktadır. Açımlayıcı faktör analizinde maddelerin bulunduğu faktör içindeki yük değerleri 40 ile .70 arasında değişmektedir. Açıklanan varyans oranları; İletişim Kurma / Sosyal Performans ölçeğinde \%11.4; Öz-Kontrol/ Düşüncelilik alt ölçeğinde \%13.2; Atılganlık alt ölçeğinde \% 7; Duygusal İstikrar/Stresle Başa Çıkma alt ölçeğinde \%4.6; Görev Yönelimi alt ölçeğinde \% 8.5; Keşfetmekten Hoşlanma alt ölçeğinde ise \% 5.2'dır.

Ölçeğin orjinalindeki güvenirlik katsayıları İletişim Kurma / Sosyal Performans alt ölçeğinde .88; Öz-Kontrol/ Düşüncelilik alt ölçeğinde .86; Atılganlık alt ölçeğinde .81; Duygusal İstikrar/Stresle Başa Çıkma alt ölçeğinde .82; Görev Yönelimi alt ölçeğinde .85; Keşfetmekten Hoşlanma alt ölçeğinde ise $.86^{\prime}$ dır. Ölçek 5'li Likert tipi bir ölçektir.

Ölçeğin puanlaması, Her zaman=5, Genellikle=4, Kısmen=3, Nadiren=2, Asla=1 şeklindedir. Ölçeğin Duygusal İstikrar/Stresle Başa Çıkma alt ölçeğindeki 5 ve 6 nolu maddeler ile Görev Yönelimi alt ölçeğindeki 6 nolu madde ters puanlanmaktadır (Mayr ve Ulich, 2009). Her bir alt ölçekten alınabilecek en yüksek puan 30 en düşük puan ise 1'dir. Ölçek öğretmenler tarafından çocuklar adına doldurulmaktadır.

İletişim Kurma / Sosyal Performans ölçeğinde çocukların akranlarıyla olan pozitif iletişim ve etkileşimine yönelik maddeler; Öz-Kontrol/ Düşüncelilik alt ölçeğinde kurallara uyma, sıra bekleme vb. özdenetime ve düşünceli davranmaya yönelik maddeler; Atılganlık alt ölçeğinde kendi haklarını uygun bir şekilde koruyabilme ile ilgili maddeler; Duygusal İstikrar/Stresle Başa Çıkma alt ölçeğinde duygusal düzenleme 
yapabilmesi ve yaşadığ yönelik maddeler; Görev Yönelimi ölçeğinde tek başına iş yapabilme, bir işe başlayabilme ve dikkatini bir iş üzerinde yoğunlaştırabilme becerilerine yönelik maddeler; Keşfetmekten Hoşlanma alt ölçeğinde ise yeni şeyler keşfetme istediğine yönelik maddeler yer almaktadır.

\section{Ölçeğin Türkçe'ye Uyarlama Çalışması ve Uygulama Süreci}

Ölçeğin dil geçerliliği için 6 dil uzmanı ile çalışılmıştır. Ölçeğin öncelikle Türkçeye çevirisi ve Türkçe formundan tekrar orijinal diline çevrilerek ölçek maddelerinde her iki formdaki tutarlılığı test edilerek ölçek maddelerinin en uygun görüldüğü Türkçe versiyonu oluşturulmuştur. Bu çalışmanın ardından okul öncesi eğitimi alanında üniversitelerde görev yapan ve her iki dile de hakim olan 3 öğretim üyesinden ölçek maddeleri ile ilgili hem içerik hem de dil tutarlılığı için görüş alınmıştır. Okul öncesi eğitim alanındaki uzmanlar ölçek maddelerinin orijinal dildeki karşılığını yansıtıp yansıtmadığını incelemişlerdir. Uzmanlar maddeleri kapsam geçerliliği açısından da incelemişlerdir. Uzmanların görüşü doğrultusunda önerilen düzeltmeler yapılarak ölçek maddelerinin uygulamaya hazır formu elde edilmiştir. Sonraki aşamada okul öncesi eğitim alanında görev yapan 5 öğretmene ölçek formu doldurtularak maddelerin anlaşılırlığı test edilmiştir. Son olarak ölçeğin Türkçe ve İngilizce formları ana dili Türkçe olan ve iyi düzeyde İngilizce bilen öğretmenler tarafindan 34 çocuk için bir hafta ara ile doldurulmuştur. Türkçe ve İngilizce ölçekten alınan toplam puanlar arasındaki Pearson Momentler Çarpımı Korelasyon Katsayısı sonucunda ölçeğin dil eşdeğerliği; İletişim Kurma / Sosyal Performans alt ölçeğinde .98; Öz-Kontrol/ Düşüncelilik alt ölçeğinde .96; Atılganlık alt ölçeğinde .98; Duygusal İstikrar/Stresle Başa Çıkma alt ölçeğinde .95; Görev Yönelimi alt ölçeğinde .98; Keşfetmekten Hoşlanma alt ölçeğinde ise .96 olarak hesaplanmış ve ölçeğin dil geçerliliğinin olduğu kabul edilmiştir.Yapılan işlemler sonrasında ölçeğin uygulamaya hazır son hali elde edilmiş ve ölçek 342 çocuk için öğretmenleri tarafından doldurulmuştur. 


\section{Verilerin Analizi}

"Sosyal Duygusal İyi Oluş Ve Psikolojik Sağlamlık Ölçeğinin (PERIK)” faktör yapısını doğrulamak için Lisrell 8.7 programında doğrulayıcı faktör analizi yapılmıştır. Doğrulayıcı Faktör Analizi (DFA) daha önce geliştirilmiş ve sınırlandırılmış bir modelin yapı olarak doğruluğu sınanarak bir ölçeğin yapı geçerliliğini ortaya koymak için yapılmaktadır. Doğrulayıcı faktör analizi, kuramsal bir yapı doğrultusunda geliştirilmiş olan bir ölçme aracının elde edilen verilere dayanarak söz konusu yapının doğrulanıp doğrulanmadığını test etmeye çalışmaktadır (Çokluk, Şekercioğlu, Büyüköztürk, 2010). Gorsuch (1983) Doğrulayıc1 Faktör Analizinin önceden belirlenen varsayımları test ettiğini, açımlayıcı faktör analizinin ise açımlayıcı bir analizin yapılmadığı durumlarda yapılması gerektiğini savunmaktadır (Gorsuch'dan akt: Çokluk vd.2010). Kültürlerarası faktör uyarlama çalışmalarında analizlere doğrudan Doğrulayıcı Faktör Analizi ile başlanması önerilmektedir. Ölçeğin faktör deseni kendi kültüründe yapılan analizlerle ortaya konulmuş ve ölçeğin yapı geçerliliğine ilişkin deneysel kanıtlar saptanmış olduğu için ölçek uyarlama çalışmalarında doğrudan faktör yapısını koruyup korumadığını belirlemek için doğrulayıcı faktör analizi ile sınanması önerilmektedir (Çokluk vd. 2010).

Alan yazında belirtilen söz konusu öneriler doğrultusunda "Sosyal Duygusal İyi Oluş ve Psikolojik Sağlamlık Ölçeği (PERIK)" için doğrulayıcı faktör analizi yapılmasına karar verilmiştir. Doğrulayıcı faktör analizi Lisrell 8.7 programında yapılmıştır. Ölçeğin faktörleri arasındaki korelasyonel ilişkiyi belirlemek için SPSS22 programı kullanılmıştır. Korelasyonel ilişki için Pearson korelasyon testi yapılmıştır. Öçeğin güvenirlik analizinde Sperman Brown iki yarı test güvenirliği ve Cronbach Alfa güvenirlik katsayıları ve test tekrar test güvenirlikleri hesaplanmıştır.

\section{Bulgular}

Araştırmanın bu kısmında Sosyal Duygusal İyi Oluş ve Psikolojik Sağlamlık Ölçeğini için yapılan Doğrulayıcı Faktör Analizi ve güvenirlik sonuçlarına yer verilmiştir. 
"Sosyal Duygusal İyi Oluş ve Psikolojik Sağlamlık Ölçeği (PERIK)" için yapılan Doğrulayıcı Faktör Analizi (DFA) sonucunda kurulan modelde programın öngördüğü modifikasyon sonucunda ölçeğin 6 faktörlü yapısı doğrulanmıştır. Doğrulayıcı faktör analizinde $t$ değerleri ve standardize edilmiş çözümler incelenmiştir. Maddelerin $t$ değerlerinin. 01 düzeyinde anlamlı olduğu saptanmıştır (Tablo 1). DFA'da t değerleri 1.96 'nın üzerinde ise .05 düzeyinde ve 2.56 'nın üzerinde ise .01 düzeyinde anlamlı olarak kabul edilmektedir (Çokluk vd, 2010). Modelde standardize edilmiş çözümlerin .01 düzeyinde anlamlı olduğu saptanmıştır (Şekil 1).

Tablo 1. Sosyal Duygusal İyi Oluş ve Psikolojik Sağlamlık Ölçeğinin (PERIK) DFA sonucunda maddelerin $t$ değerleri ve anlamlılık düzeyleri

\begin{tabular}{|c|c|c|c|}
\hline Ölçek Faktörleri & Madde No & $\mathbf{t}$ & p \\
\hline \multirow{6}{*}{ Faktör 1} & M 1 & 11.17 & 0.001 \\
\hline & M 2 & 10.18 & 0.001 \\
\hline & M3 & 11.37 & 0.001 \\
\hline & M 4 & 10.51 & 0.001 \\
\hline & M 5 & 11.47 & 0.001 \\
\hline & M 6 & 11.33 & 0.001 \\
\hline \multirow{6}{*}{ Faktör 2} & M 7 & 11.24 & 0.001 \\
\hline & M 8 & 9.93 & 0.001 \\
\hline & M9 & 11.13 & 0.001 \\
\hline & M 10 & 10.58 & 0.001 \\
\hline & M 11 & 10.98 & 0.001 \\
\hline & M12 & 12.15 & 0.001 \\
\hline \multirow{6}{*}{ Faktör 3} & M 13 & 12.38 & 0.001 \\
\hline & M 14 & 10.07 & 0.001 \\
\hline & M 15 & 9.81 & 0.001 \\
\hline & M 16 & 11.36 & 0.001 \\
\hline & M 17 & 12 & 0.001 \\
\hline & M 18 & 10.91 & 0.001 \\
\hline \multirow{6}{*}{ Faktör 4} & M 19 & 11.75 & 0.001 \\
\hline & M 20 & 9.54 & 0.001 \\
\hline & M 21 & 9.1 & 0.001 \\
\hline & M 22 & 11.03 & 0.001 \\
\hline & M 23 & 12.56 & 0.001 \\
\hline & M 24 & 12.64 & 0.001 \\
\hline \multirow{7}{*}{ Faktör 5} & M 25 & 10.79 & 0.001 \\
\hline & M 26 & 10.44 & 0.001 \\
\hline & M 27 & 11.41 & 0.001 \\
\hline & M 28 & 9.93 & 0.001 \\
\hline & M 29 & 10.57 & 0.001 \\
\hline & M 30 & 12.86 & 0.001 \\
\hline & M 31 & 11.94 & 0.001 \\
\hline
\end{tabular}




\begin{tabular}{llll} 
& M 32 & 11.52 & 0.001 \\
Faktör 6 & M 33 & 11.78 & 0.001 \\
& M 34 & 9.62 & 0.001 \\
& M 35 & 10.23 & 0.001 \\
M 36 & 11.33 & 0.001 \\
\hline
\end{tabular}

${ }^{*} \mathrm{p}<0.01$

Tablo 1'de maddelerin $\mathrm{t}$ değerleri ve anlamlılık düzeylerine; Şekil 1'de ise DFA sonucundaki ölçeğe ilişkin Yapısal Eşitlik Modeline ve Standardize Değerlere yer verilmiştir.

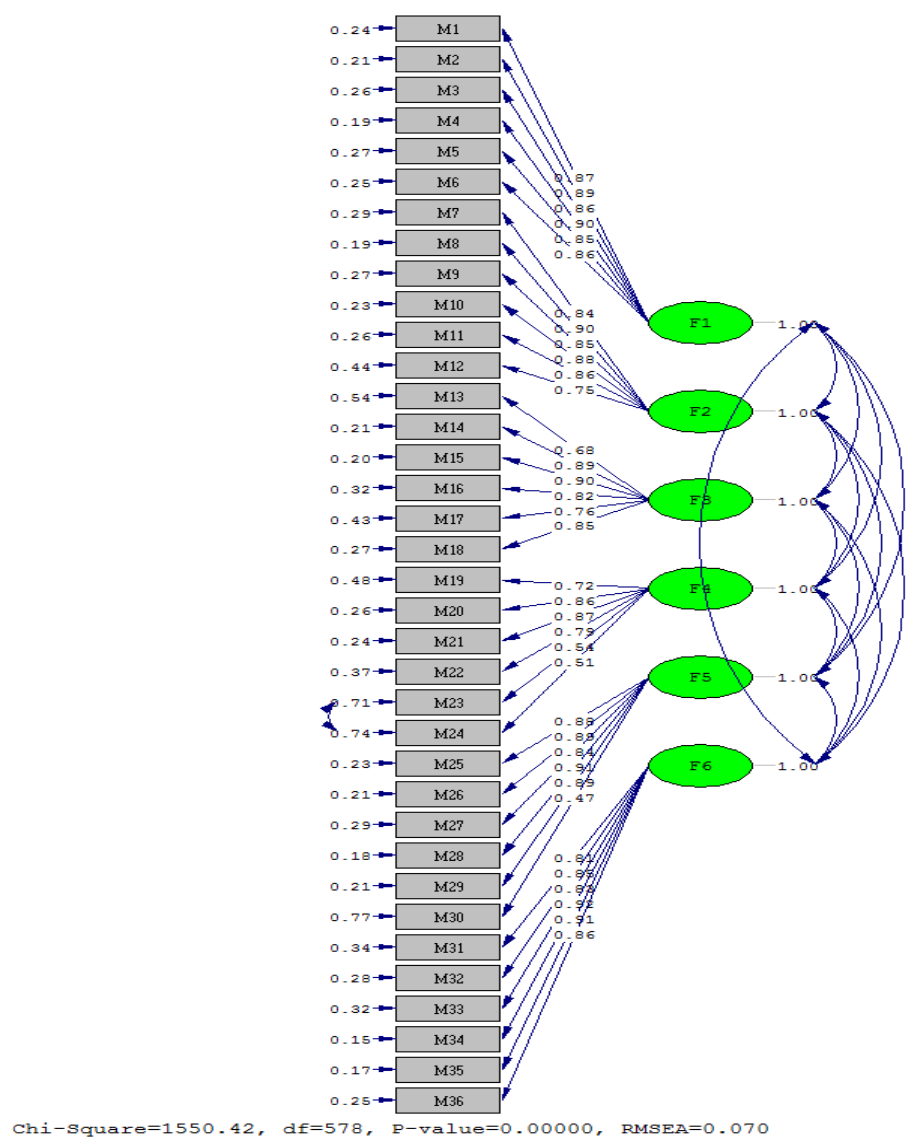

Şekil 1. Ölçeğe ilişkin Yapısal Eşitlik Modeli ve Standardize Değerleri 
Tablo 2'de ölçeğin Doğrulayıcı Faktör Analizi sonucunda saptanan uyum iyiliği indeksleri verilmiştir.

Tablo 2. Sosyal Duygusal İyi Oluş ve Psikolojik Sağlamlık Ölçeği (PERIK) altı faktörlü model için uyum iyiliği indeksleri

\begin{tabular}{llll}
\hline \multicolumn{1}{c}{ İndeks } & \multicolumn{1}{c}{ Mükemmel Uyum } & İyi Uyum & Önerilen Modelde \\
\hline$\chi 2 /$ sd & $<2$ & $<5$ & $1550.42 / 578=2.68$ \\
RMSEA & $<0.05$ & $<0.08$ & 0.07 \\
RMR & $<0.05$ & $<0.08$ & 0.057 \\
SRMR & $<0.05$ & $<0.08$ & 0.06 \\
CFI & $>0.95$ & $>0.90$ & 0.98 \\
NFI & $>0.95$ & $>0.90$ & 0.97 \\
NNFI & $>0.95$ & $>0.90$ & 0.98 \\
GFI & $>0.95$ & $>0.90$ & 0.80 \\
\hline
\end{tabular}

${ }^{* *} \mathrm{p}<0.01$

Tablo 2'ye göre doğrulayıcı faktör analizi sonucunda modelin $\chi^{2}$ $=1550.42$, serbestlik derecesi $(\mathrm{sd})=578, \chi 2 / \mathrm{sd}=2,68$ olarak saptanmiştır. Model istatistiksel olarak anlamlıdır ( $<<0.01)$. Ki-Kare/sd oranı 3 'ün altında olması mükemmel uyuma, 5 'in altında olması ise iyi uyuma işaret etmektedir. Yol şemasında ölçeğin diğer uyum ölçülerine bakıldığında REMSEA = 0,07 olarak saptanmıştır. RMSEA'nın .05 'ten küçük olması mükemmel uyuma, .08'den küçük olması da iyi uyuma işaret etmektedir. Ölçeğin RMR uyum indeksinin 0.057 ve SRMR'nin ise 0.060 olduğu saptanmıştır. RMR'nin .05 'in altında olması mükemmel uyuma .08 'in altında olması ise iyi uyuma işaret etmektedir (Çokluk vd.,2010:272; Schermelleh-Engel ve Moosbrugger, 2003).

Ölçeğin diğer uyum indekslerine bakıldığında, CFI=0.98, NFI=0.97, NNFI $=0.98$ ve GFI $=0,80$ olarak belirlenmiştir. NNFI, NFI ve CFI indekslerinin .95'in üzerinde olması mükemmel uyuma, .90'ın üzerinde olması ise iyi uyuma işaret etmektedir (Çokluk vd., 2010). Bu kapsamda NNFI, NFI ve CFI değerlerinin mükemmel uyuma sahip olduğunu söyleyebilmek mümkündür. GFI örneklem büyüklügün̈den etkilenen uyum indeksi olması nedeniyle ölçeğin GFI indeksinin düşük olması örneklem büyüklüğü ile açıklanabilir. GFI indeksi büyük örneklemlerde daha yüksek sonuçlar vermektedir (Çokluk vd., 2010). Ölçeğin uyum indeksleri değerlendirildiğinde uyarlanan ölçeğin 6 faktörlü yapı için model veri uyumunun sağlandığını göstermektedir. 
Tablo 3'te "Sosyal Duygusal İyi Oluş ve Psikolojik Sağlamlık Ölçeğinin (PERIK)" faktör puanları arasındaki korelasyona ilişkin bulgulara yer verilmiştir.

Tablo 3. Sosyal Duygusal İyi Oluş ve Psikolojik Sağlamlık Ölçeğinin (PERIK) faktörleri arasndaki ilişskiye yönelik Pearson Korelasyon tablosu

\begin{tabular}{llrrrrrr}
\hline Ölçek & & \multicolumn{1}{c}{ Faktör 1 } & \multicolumn{1}{c}{ Faktör 2 } & Faktör 3 & Faktör 4 & Faktör 5 & \multicolumn{1}{c}{ Faktör 6 } \\
\hline \multirow{2}{*}{ Faktör 1 } & $\mathrm{r}$ & 1 & $.583^{* *}$ & $.758^{* *}$ & $.695^{* *}$ & $.601^{* *}$ & $.729^{* *}$ \\
& $\mathrm{p}$ & & .000 & .000 & .000 & .000 & .000 \\
& $\mathrm{n}$ & 342 & 342 & 342 & 342 & 342 & 342 \\
& $\mathrm{r}$ & $.583^{* *}$ & 1 & $.451^{* *}$ & $.635^{* *}$ & $.648^{* *}$ & $.532^{* *}$ \\
Faktör 2 & $\mathrm{p}$ & .000 & & .000 & .000 & .000 & .000 \\
& $\mathrm{n}$ & 342 & 342 & 342 & 342 & 342 & 342 \\
& $\mathrm{r}$ & $.758^{* *}$ & $.451^{* *}$ & 1 & $.589^{* *}$ & $.485^{* *}$ & $.734^{* *}$ \\
Faktör 3 & $\mathrm{p}$ & .000 & .000 & & .000 & .000 & .000 \\
& $\mathrm{n}$ & 342 & 342 & 342 & 342 & 342 & 342 \\
& $\mathrm{r}$ & $.695^{* *}$ & $.635^{* *}$ & $.589^{* *}$ & 1 & $.560^{* * *}$ & $.631^{* *}$ \\
Faktör 4 & $\mathrm{p}$ & .000 & .000 & .000 & & .000 & .000 \\
& $\mathrm{n}$ & 342 & 342 & 342 & 342 & 342 & 342 \\
& $\mathrm{r}$ & $.601^{* *}$ & $.648^{* *}$ & $.485^{* *}$ & $.560^{* *}$ & 1 & $.626^{* * *}$ \\
Faktör 5 & $\mathrm{p}$ & .000 & .000 & .000 & .000 & & .000 \\
& $\mathrm{n}$ & 342 & 342 & 342 & 342 & 342 & 342 \\
& $\mathrm{r}$ & $.729^{* *}$ & $.532^{* * *}$ & $.734^{* *}$ & $.631^{* *}$ & $.626^{* *}$ & 1 \\
Faktör 6 & $\mathrm{p}$ & .000 & .000 & .000 & .000 & .000 & \\
& $\mathrm{n}$ & 342 & 342 & 342 & 342 & 342 & 342 \\
\hline
\end{tabular}

${ }^{* *} \mathrm{p}<0.01$

Tablo 3 incelendiğinde "Sosyal Duygusal İyi Oluş ve Psikolojik Sağlamlık Ölçeğinin (PERIK)" alt ölçekleri arasında orta ve yüksek düzeyde pozitif yönde ve anlamlı ilişki bulunduğu görülmektedir $(\mathrm{p}<0.01)$.

\section{Güvenirlik Analizleri}

Tablo 4 'de "Sosyal Duygusal İyi Oluş ve Psikolojik Sağlamlık Ölçeği” nin Cronbach Alpha ve Sperman Brown İki Yarı Test güvenirlik testleri; Tablo 5 'te ise yaşlara göre Cronbach Alpha güvenirliği verilmiştir. 
Tablo 4. Sosyal Duygusal İyi Oluş ve Psikolojik Sağlamlık Ölçeğinin (PERIK) Cronbach Alpha ve Sperman Brown İki Yarn Test güvenirlik analizi

\begin{tabular}{lcc}
\hline $\begin{array}{l}\text { Sosyal Duygusal İyi Oluş ve Psiko- } \\
\text { lojik Sağlamlık Ölçeği }\end{array}$ & Cronbach's Alpha & $\begin{array}{c}\text { Sperman Brown } \\
\text { İki Yarı Test Güvenir- } \\
\text { liği }\end{array}$ \\
\hline Faktör 1 & .95 & .94 \\
Faktör 2 & .93 & .92 \\
Faktör 3 & .92 & .88 \\
Faktör 4 & .86 & .74 \\
Faktör 5 & .91 & .88 \\
Faktör 6 & .94 & .91 \\
\hline
\end{tabular}

Tablo 4 incelendiğinde “Sosyal Duygusal İyi Oluş ve Psikolojik Sağlamlık Ölçeği" nin güvenirlik sonuçlarının yüksek olduğu görülmektedir. Ölçeğin Alpha güvenirlik kat sayıları Faktör 1 için =.95, Faktör 2 için=.93, Faktör 3 için=.92, Faktör 4 için =.86, Faktör 5 için .91, Faktör 6 için =94'tür. Sperman Brown İki Yarı Test Güvenirliği ise Faktör 1 için $=.94$, Faktör 2 için=.92, Faktör 3 için=.88, Faktör 4 için =.74, Faktör 5 için .88, Faktör 6 için $=91^{\prime}$ dir.

Tablo 5.Sosyal Duygusal İyi Oluş ve Psikolojik Sağlamlık Ölçeğinin (PERIKK) çocuklarnn yaşlarnna göre Cronbach Alpha analizleri

\begin{tabular}{lccc}
\hline Sosyal Duygusal İyi & \multicolumn{3}{c}{ Cronbach's Alpha } \\
\cline { 2 - 4 } $\begin{array}{l}\text { Oluş ve Psikolojik Sağ- } \\
\text { lamlık Ölçeği }\end{array}$ & 36-48 Ay & $\mathbf{4 9 - 6 0 ~ A y ~}$ & $\mathbf{6 1 - 7 2}$ Ay \\
\hline Faktör 1 & & & .95 \\
Faktör 2 & .92 & .95 & .94 \\
Faktör 3 & .88 & .93 & .94 \\
Faktör 4 & .90 & .90 & .87 \\
Faktör 5 & .72 & .88 & .90 \\
Faktör 6 & .85 & .92 & .96 \\
\hline
\end{tabular}

Tablo 5 incelendiğinde yaş grubuna göre; ölçeğin güvenirlik katsay1ları 36-48 aylık çocuklarda .72 ile .96 arasında; 49-60 aylık çocuklarda .88 ile .95 arasında ve 61-72 aylık çocuklarda ise .87 ile.96 arasında değişmektedir. Psikolojik testlerde ölçeğin güvenirlik katsayısının .70 ve daha yüksek olmasının genel olarak ölçeğin güvenirliği için yeterli olduğu belirtilmektedir (Büyüköztürk,2007). Tezbaşaran (1997), likert tipi bir ölçekte yeterli sayılabilecek bir güvenirlik katsayısının olabildiğince 1'e 
yakın olması gerektiğini ifade etmektedir Kalaycı (2009) ise bir ölçeğin güvenirliğinde Cronbach Alpha $(\alpha)$ katsayısı; .00 $\leq \alpha<.40$ ise ölçeğin güvenilir olmadığını; .40 $\leq \alpha<.60$ ise ölçek güvenilirliğinin düşük olduğunu; .60 $\leq \alpha<.80$ ise ölçeğin oldukça güvenilir olduğunu; . $80 \leq \alpha<1,00$ ise ölçeğin yüksek derecede güvenilir olduğunu belitmektedir.

“Sosyal Duygusal İyi Oluş ve Psikolojik Sağlamlık Ölçeği"nin güvenirlik katsayıları incelendiğinde, ölçeğin 48-72 aylık çocuklarda yüksek güvenirliğe sahip olduğu; 36-48 aylık çocuklarda ise 4. Faktörde oldukça güvenilir, diğer faktörlerde ise yüksek güvenirliğe sahip olduğu görülmektedir.

\section{Test Tekrar Test Güvenirliği}

“Sosyal Duygusal İyi Oluş ve Psikolojik Sağlamlık Ölçeği" nin Test Tekrar Test güvenirlik analizleri için 30 çocuğa bir hafta arayla ölçek tekrar uygulanmıştır. Test Tekrar Test güvenirliği İletişim Kurma / Sosyal Performans alt ölçeğinde .99; Öz-Kontroll Düşüncelilik alt ölçeğinde .98; Atılganlık alt ölçeğinde .99; Duygusal İstikrar/Stresle Başa Çıkma alt ölçeğinde .98; Görev Yönelimi alt ölçeğinde .94; Keşfetmekten Hoşlanma alt ölçeğinde ise $.98^{\prime}$ dir.

\section{Sonuç}

Araştırmada Mayr ve Ulich (2009) tarafından geliştirilen "Sosyal Duygusal İyi Oluş ve Psikolojik Sağlamlık Ölçeği"nin geçerlik ve güvenirlik çalışması yapılmıştır. Ölçeğin dil geçerliliği için altı dil uzmanı, üç okul öncesi eğitimi alan uzmanı ve beş okul öncesi öğretmeni ile çalışılmıştır. Ölçeğin Türkçeye uygunluğu açısından uzmanların görüşleri doğrultusunda düzenlemeler yapılarak ölçeğin uygulamaya hazır şekli elde edilmiştir. Ölçeğin İngilizce ve Türkçe formları arasındaki tutarlılığı saptamak amacıyla ölçek ana dili Türkçe olan ve iyi derecede İngilizce bilen okul öncesi öğretmenleri tarafından 34 çocuk için bir hafta ara ile doldurulmuştur. Ölçeğin İngilizce ve Türkçe formları arasındaki Pearson Korelasyon Katsayısının .96 ile .99 arasında olduğu saptanmıştır. Ölçek maddeleri 36-72 aylık 342 okul öncesi dönem çocuğu için sınıftaki öğretmenleri tarafından, çocuğu tanımak için gerekli olan en az 2 ay süreli sınıf içi 
etkinlikler sırasındaki gözlemlerine dayalı olarak doldurulmuştur. Öğretmenlerden çocuk bir davranışı her zaman gösteriyorsa $5=H e r$ zaman seçeneğini; genellikle gösteriyorsa $4=$ Genellikle seçeneğini; zaman zaman gösteriyorsa 3=Kısmen seçeneğini, nadiren gösteriyorsa 2=Nadiren seçeneğini ve hiç göstermiyorsa $1=$ Asla seçeneğini işaretlemeleri istenmiştir. Elde edilen veriler ile geçerlik güvenirlik analizleri yapılmıştır.

Ölçeğin faktör yapısını doğrulamak için Doğrulayıcı Faktör Analizi yapılmış ve analiz sonucunda kurulan modelde ölçeğin orjinalindeki altı faktörlük yapısı doğrulanmıştır. Ölçeğin uyum indeksleri değerlendirildiğinde ölçeğin model veri uyumunu sağladığı saptanmıştır. Ölçeğin faktörleri arasındaki korelasyon için Pearson Korelasyon testi yapılmış ve ölçeğin faktörleri arasında orta ve yüksek düzeyde ve anlamlı ilişki bulunmuştur.

Ölçeğin güvenirliği için Cronbach's Alpha güvenirlik katsayıları .86 ile .95 arasında; Sperman Brown İki Yarı Test güvenirlik katsayıları .74 ile .94 arasındadır. Ölçeğin Alpha güvenirlik katsayısı 36-48 aylık çocuklarda .72 ile .96 arasında; 49-60 aylık çocuklarda .88 ile .95 arasında ve 61-72 aylık çocuklarda ise .87 ile.96 arasındadır. Bu verilere göre ölçek oldukça güvenilir/yüksek güvenilirliğe sahiptir. Ölçeğin Test Tekrar Test güvenirlik katsayıları ise .94 ile .99 arasında değişmektedir. Ölçeğin güvenirlik analizleri yüksek düzeyde güvenirliğe sahip olduğunu göstermektedir.

Yapılan analizler sonucunda Mayr ve Ulich (2009) tarafından geliştirilen "Sosyal Duygusal İyi Oluş ve Psikolojik Sağlamlık Ölçeği”nin 6 alt ölçek ve 36 maddelik yapısı ile 36-72 aylık Türk çocukları için geçerli ve güvenilir bir ölçme aracı olduğu sonucuna ulaşılmıştır. Ölçeğin okul öncesi dönem çocuklarında hem durum saptamasına ilişkin yapılabilecek çalışmalarda hem de okul öncesinde program geliştirme çalışmalarına önemli katkı sağlayacağı düşünülmektedir. 
EXTENDED ABSTRACT

\title{
Validity and Reliability Study of Social Emotional Well-Being and Psychological Resilience Scale for Preschool Children (PERIK)
}

\author{
Saide Özbey
}

Gazi University

Social and emotional well-being is a broad phrase including emotions, behaviours, relations, objectives and personal powers within the scope of social and emotional development. Social and emotional development covers some skills that children need to develop to be successful at school and generally in life. These are the skills of a person of identifying and understanding the emotions, proper reading and understanding the emotional conditions of others, managing strong emotions, organizing behaviours, developing empathy and starting and maintaining interpersonal relations. Social and emotional development are related to psychological resilience that includes power and capacity such as "mental health" and "psychological resilience" necessary to maintain a productive life and to overcome the problems faced and that allows contribution to both oneself and to the society.

Psychological resilience is defined to be "the skill to quickly recover, get well and recuperate from a disease, depression or another bad condition". The concept of psychological resilience has two dimensions including "being subject to significant threat and severe trouble" and "providing the positive adaptation despite immense attacks on developmental process".

Children are born with a capacity of psychological resilience. Psychological resilience is a condition that is worked with throughout life. Therefore, it is essential to empower psychological resilience during early periods. During early childhood, children learn by observation how their parents cope with the events causing daily stress. As children grow, new cognitive, social and behavioural expectations start to grow in both family and school lives. It becomes more and more difficult to new developmental tasks and academic demands with school life if they cannot 
assume new developmental tasks in the preschool period. Therefore, it is essential to understand how psychological resilience will be developed and to support a child at this point.

Howell, Graham-Bermann, Czyz and Lilly (2010) conceptualized psychological resilience as the emotional organization and strength in positive social skills which are the two fields with vital importance in the development of preschool children. Becoming more competent in the interaction and management of behaviours and emotions develop the social skills of children and enable them to have more interactions with others. Establishing positive relations with peers is considered to be important for mental health during preschool and primary school years. Emotional organization, social skills, school readiness and problematic behaviours are considered to be the basic issues that need to be addressed for the development of psychological resilience.

Children with supported psychological resilience are stated to be more resistant against difficulties in their adulthood, have a healthier and longer life, be happier in their relations, more successful at school and work and have less possibility to fall into depression. Therefore, considering the fact that the preschool period is a developmental infrastructure that will be a basis for the adulthood, it is an undisputable fact that psychological resilience should be supported from the preschool period on. The literature search indicated that the studies on psychological resilience are very limited in the preschool period and mostly focus on adults. Although there are studies on social skills, emotional organization, anxiety, emotional intelligence, self-organization and selfconfidence which are sources for psychological resilience in the preschool period, the studies dealing with psychological resilience as a whole are very limited. Nevertheless, the measurement instruments to measure psychological resilience during preschool period are very limited too. It is essential to develop different measurement instruments that may measure psychological resilience in the preschool period and submit them to the literature.

Accordingly the research was designed to conduct the validity and reliability study of the "Social Emotional Well-being and Psychological Resilience Scale for Preschool Children (PERIK)" developed by Mayr and Ulich (2009). 
The sample of the study consists of 342 children in the ages of 36-72 months attending to the public and private preschools in the districts of Yenimahalle and Altındağ in Ankara. The language validity of the scale was conducted by six language specialists. The items of the scale were reviewed subsequently by three specialists who have good command of the field of preschool education and of both languages. They tested the scale for comprehensibility and checked whether the items correspond to the original statements. The finalized items were filled in by five preschool teachers and it comprehensibility of the items was tested.

Confirmatory Factor Analysis was conducted for the factors of the scale and the 6-factor structure in the original scale was confirmed. The fit indices of the scale were examined, and the scale was found to have a good and perfect fit. Pearson Correlation test was conducted for the correlation between the factors of the scale and it was determined that there was a medium and high significant relation between the factors of the scale. The Alpha reliability coefficients of the scale vary between , 86 and ,95. As a result of the study, it was found that the scale is a valid and reliable measurement instrument for the Turkish children.

\section{Kaynakça / References}

Ağırkan, M. ve Kağan, M. (2017). Üniversite öğrencilerinin değer yönelimleri ile psikolojik dayanıklılık düzeyleri arasındaki ilişki. Erzincan Üniversitesi Eğitim Fakültesi Dergisi,19(3), 239-262.

Alvord, M. K., ve Grados, J. (2005). Enhancing resilience in children: A proactive approach. Professional Psychology Researrch and Practice, 36, 238-245. http://dx.doi.org/10.1037/0735-7028.36.3.238.

Anthony, E. J. (1987a). Children at high risk for psychosis growing up successfully. E. J. Anthony ve B. J. Cohler (Eds.), In The Invulnerable child (pp. 147-184). New York: Guilford Press.

Atkinson, R.L., Atkinson, R.C., Smith, E.E., Bem, D.J. ve NolenHeoksema, S. (1999). Psikolojiye giriş. İstanbul: Arkadaş Yayınları.

Balaban Dagal, A. ve Bayındır, D. (2018). Okul öncesi dönem çocuklarının ego sağlamlık düzeylerinin incelenmesi. Erken Çocukluk Çalışmaları Dergisi, 2(1), 132-150. 
Basım, H. N. ve Çetin, F. (2011). Yetişkinler için psikolojik dayanıklılık ölçeği'nin güvenilirlik ve geçerlilik çalışması. Türk Psikiyatri Dergisi, 22(2), 104-114.

Bektaş, M., ve Özben, Ş. (2016). Evli bireylerin psikolojik dayanıklılık düzeylerinin bazı sosyo-demografik değişkenler açısından incelenmesi. Celal Bayar Üniversitesi Sosyal Bilimler Dergisi, 14(1), 215240.

Best Start Resource Centre (2018). Building resilience in young children. http://www.ecdc.syr.edu/wp-content/uploads/BuildingResilience-1.pdf. Erişim Tarihi:10.09.2018.

Block, J. (1969). Parents of schizophrenic, neurotic, asthmatic, and congenitally ill children. A comparative study. Arch Gen Psychiatr, 20(6), 659-674.

Block, J. H., ve Block, J. (1980). The role of ego-control and ego-resiliency in the organization of behavior. In W. A. Collins (Ed.), Development of cognition, affect and social relations: The Minnesota symposia on child psychology, 13, (pp.39-101). Hillsdale, NJ: Erlbaum.

Bronfenbrenne, U. (1979). The ecology of human development. Cambridge, Massachusetts, and London, England: Harvard University Press.

Büyüköztürk, Ş. (2007). Sosyal bilimler için veri analizi. Ankara: Pegem Yayınevi.

Cicchetti, D., ve Rogosch, F. A. (1997). The role of self-organization in the promotion of resilience in maltreated children. Development and Psychopathology, 9, 797-815.

Çokluk, Ö., Şekercioğlu, G. ve Büyüköztürk, Ş. (2010). Sosyal bilimler için çok değişkenli istatistik. SPSS ve Lisrell uygulamaları. Ankara: Pegem Yayınevi.

Çömlekçi, N. (2001). Bilimsel araştırma yöntemi ve istatistiksel anlamlllık sinamaları. Ankara: Bilim Teknik Yayınevi.

Denham, S. A. (2006). Social-emotional competence as support for school readiness: What is it and how do we assess it? Early Education and Development, Special Issue: Measurement of school Readiness, 17, 57-89.

Earvolino-Ramirez, M. (2007). Resilience: A concept analysis. Nursing forum, 2(42),73-82. 
Erdem, E. (2017). Okul öncesi eğitime devam eden 4-5 yaşındaki çocukların yılmazlık özellikleri ve yılmazlı̆̆ı destekleyici faktörlerin incelenmesi. Yayınlanmamış Yüksek Lisans Tezi. Gazi Üniversitesi Eğitim Bilimleri Enstitüsü, Ankara.

Ferić, M., Maurović, I. ve Žižak, A. (2016). Izazovi istraživanja otpornosti obitelji. Kriminologija i socijalna integracija, 24(1), 3-25.

Fraser, M. W., Richman, J. M. ve Galinsky, M. J. (1999). Risk, protection and resilience: toward a conceptual framework for social work practice. Social Work Research, 23, 129-208.

Garmezy, N. (1991) Resiliency and vulnerability to adverse developmental outcomes associated with poverty. American Behavioral Scientist, 34,416- 430. http://dx.doi.org/10.1177/0002764291034004003.

Graham, A. (2011). Strengthening young people's social and emotional wellbeing. Centre for Children and Young People Background Briefing Series, no.7. Lismore: Centre for Children and Young People, Southern Cross University. https://epubs.scu.edu.au/ccyp_pubs/42.(20.11.2018).

Greene, R. R. (2002). Holocaust survivors: a study in resilience. Journal of Gerontological Social Work, 37(1), 3-18.

Gizir, C. A. (2016). Psikolojik sağlamlık, risk faktörleri ve koruyucu faktörler üzerine bir derleme çalışması. Türk Psikolojik Danışma ve Rehberlik Dergisi, 3(28), 113-128.

Graber, R., Pichon, F. ve Carabine, E. (2015). Psychological resilience: state of knowledge and future research agendas. Overseas Development Institute, October. https://www.odi.org/sites/odi.org.uk/files/odiassets/publications-opinion-files/9872.pdf.

Hamilton, M. ve Redmond, G. (2010). Conceptualisation of social and emotional wellbeing for children and young people, and policy implications for the Australian Research Alliance for Children and Youth and the Australian Institute of Health and Welfare http://australianchildwellbeing.com.au.(20.11.2018).

Howell, K. H., Graham-Bermann, S.A., Czyz, E. ve Lilly, M. (2010). Assessing resilience in preschool children exposed to intimate partner violence. Violence and Victims, 25(2), 150-164.

Howell, K. H. (2011). Assessing resilience in preschool children exposed to intimate partner violence: Utilizing multiple informants and evaluating 
the impact of the Preschool Kids' Club. (Unpublished doctoral dissertation). The University of Michigan, Ann Arbor.

Hall, J., Sylva, K., Melhuish, E., Sammons, P., Siraj-Blatchford, I. ve Taggar, B. (2009). The role of pre-school quality in promoting resilience in the cognitive development of young children. Oxford Review of Education, 35(3) 1-43.

Kalaycı, Ş. (2009). SPSS uygulamalı çok değişkenli istatistik teknikleri. Ankara: Asil Yayınları.

Luthar, S. S. (1996). Resilience: A construct of value? Paper presented at the 104th Annual Convention of the American Psychological Association, August 1996, Toronto, Ontario.

Luthar, S. S., Cichetti, D. ve Becker, B. (2000). The construct of resilience: A critical evaluation and guidelines for future work. Child Development, $71,543-562$.

Macmillandictionary (2018). https://macmillandictionary.com /resilienc. Erişim Tarihi:20.11.2018.

Masten, A. S., ve Garmezy, N. (1985). Risk, vulnerability, and protective factors in developmental psychopathology. In B. Lahey, A. E. Kazdin (Eds.), Advances in clinical child psychology, 8(pp. 1-52). New York, NY: Plenum Press.

Masten, A. S. (1994). Resilience in individual development: Successful adaptation despite risk and adversity: Challenges and prospects. In M. Wang ve E. Gordon (Eds.), Educational resilience in inner city America: Challenges and prospects (pp.3-25). Hillsdale, NJ: Lawrence Erlbaum.

Masten, A. S. (1997). Resilience in children at-risk. Resiliency-A paradigm shift for Schools. http://www.education.umn.edu/carei/Reports/Rpractice/Spring97/resilience.htm.20.11.2019.

Masten, A. S., Best, K. M. ve Garmezy, N. (1990). Resilience and development: Contributions from the study of children who overcome adversity. Development and Psychopathology,2, 425-444. http://dx.doi.-org/10.1017/S0954579400005812.

Mayr, T. ve M. Ulich. (2003). Seelische gesundheit bei kindergartenkindern. in elementar. Padagogik nach pisa, W.E. Fthenakis (Ed.), (pp.190-205). Freiburg: Herder. 
Mayr, T. ve Ulich, M. (2006). Perik: Positive entwicklung und resilienz im kindergartenalltag. Staatinstitut fur frühpädagogik IFP.

Mayr, T. ve Ulich, M. (2009). Social-Emotional welll-being and resilience of children in early childhood settings- PERIK: An empirically based observation scale for practitioners. Early Years. An International Journal of Research and Development, 29(1), 45-57.

Miljević-Riđički, R., Plantak, K. ve Bouillet, D. (2017). Resilience in preschool children-the perspectives of teachers, parents and children. International Journal of Emotional Education, 9(2), 31-43.

Murphy, L. B. (1987). Further reflections on resilience. (Ed: E. J. Anthony ve B. J. Cohler) The Invulnerable Child. New York: The Guilford Press.

Önder, A. ve Gülay Ogelman, H. (2011). Beş-Altı yaş çocukları için ego sağlamlı̆̆ı ölçeği'nin (öğretmen-anne-baba formları) güvenirlik geçerlik çalışması. Uluslararası Hakemli Akademik Sosyal Bilimler Dergisi, 2(1),05-21.

Özen, Y. ve Gül, A. (2007). Sosyal ve eğitim bilimleri araştırmalarında evren-örneklem sorunu. KKEFD /] OKKEF, 1, 394-422.

Reivich, K. ve Shatte', A. (2002). The resilience factor. New York: Broadway Books.

Schermelleh-Engel, K. ve Moosbrugger, H. (2003). Evaluating the fit of structural equation models: Test ofsignificance and descriptive goodness-of-fit measures. Methods of Psychological Research Onli$n e, 8(2), 23-74$.

Saraçoğlu, A. S. ve Kumral, O. (2007). Sinıf öğretmenliği son sınıföğrencilerinin öğretmenlik mesleğine yönelik yeterlik algılarl, kaygılar ve akademik güdülenme düzeylerinin çeşitli değişkenler açısından incelenmesi. Anadolu Üniversitesi Eğitim Fakültesi VI. Ulusal Sınıf Öğretmenliği Eğitimi Sempozyumu. 27-29 Nisan 2007 Eskişehir (ss.354-359).

Sipahioğlu, Ö. (2008). Farklı risk gruplarmdaki ergenlerin psikolojik sağlamlıklarının incelenmesi. (Yüksek Lisans Tezi). Selçuk Üniversitesi Sosyal Bilimler Enstitüsü, Konya.

Şahan Aktan, B. ve Önder, A. (2018). Okul öncesi dönemde psikolojik dayanıklılık. Ĕğitim Kuram ve Uygulama Araştırmaları Dergisi, 4 (2),20-30. 
Tezbaşaran, A. (1997). Likert tipi ölçek gelistirme kılavuzu (İkinci Baskı). Ankara: Türk Psikologlar Derneği Yayınları.

Ungar, M. (2011). The social ecology of resilience: addressing contextual and cultural ambiguity of a nascent construct. American Journal of Orthopsychiatry, 81, 1-17.

Ünsal, F. Ö. ve Balat, G. U. (2016). The effects of "resilience program for preschool children" on 5-year-old children's social skills. Eğitim Kuram ve Uygulama Araştırmaları Dergisi, 2(2), 1-11.

Werner, E.E.; Bierman J.M. ve French F.E. (1971). The children of Kauai Honolulu. Hawaii: University of Hawaii Press.

Werner, E. ve Smith, R. (1977). Kauai's children come of age. Honolulu: University of Hawaii Press.

Werner, E. ve Smith, R. (1982). Vulnerable but Invincible: A longitudinal study of resilient children and youth. New York: McGraw-Hill.

Werner E. ve Smith R. (1992). Overcoming the odds: high risk children from birth to adulthood. Ithaca, NY.: Cornell University Press.

Wang, M. C. (1995). Educational Resilience: An emergent construct. Publication Series. ERIC. ED399312.

Yule, K. (2017). Caregivers' role in fostering resilience in preschoolers. Master's Theses (2009). 427. http://epublications. marquette.edu/the ses_o-pen/427

\section{Kaynakça Bilgisi / Citation Information}

Özbey, S. (2019). Okul öncesi çocuklar için sosyal duygusal iyi oluş ve psikolojik sağlamlık ölçeğinin (PERIK) geçerlik güvenirlik çalışması. OPUS-Uluslararası Toplum Araştırmaları Dergisi, 10(17), 756786. DOI: 10.26466/opus.518062 